\title{
MOLECULAR APPROACH OF GOSSYPOL-INDUCED REPRODUCTIVE TOXICITY IN MALE RABBITS. ELECTROPHORETIC PATTERN OF SEMINAL PLASMA PROTEINS
}

\author{
T. A. Taha, W. F. Shaaban, F. D. EL-Nouty and M. H. Salem \\ Department of Animal Production, Faculty of Agriculture (El-Shatby), Alexandria \\ University, Alexandria, Egypt
}

\section{SUMMARY}

Mammalian seminal plasma contains many distinct components which are important for spermatozoal function and survival. Recent studies clearly indicated that gossypol has pronounced hazardous effects on seminal characteristics and seminal plasma constituents in male rabbits, which may lead to deleterious productive and reproductive performance. We examined the possible deleterious effects of two sublethal doses (4 and $20 \mathrm{mg} / \mathrm{kg}$ of body weight; every other day) of gossypol on the electrophoretic pattern of rabbit seminal plasma proteins. The experiment lasted $16 \mathrm{wks}$ and included two periods: a treatment period (first $8 \mathrm{wks}$ ) where the animals were given the tested materials, and a recovery period (second 8 wks) where drugs were withdrawn. A total of twenty two bands were identified ranging from a high $200.0 \mathrm{kDa}$ protein down to a low $11.0 \mathrm{kDa}$ protein. Denistometric analysis of the stained gel patterns indicated that gossypol treatment revealed significant increases in the content of bands having 66.0, 31.0 and 23.0 $\mathrm{kDa}$, while the two bands having 70.0 and $11.0 \mathrm{kDa}$ were found to decrease in its content. Gossypol treatment also caused considerable decreases in the three major bands (33.0, 21.5 and $13.0 \mathrm{kDa}$ ), and the highest decrease was in the $33.0 \mathrm{kDa}$ band. Gossypol seems to increase the content of some seminal plasma peptide bands associated with increasing acrosome alterations, dead and abnormal sperm and destabilization of sperm structure. However, other peptide bands related to reduction of sperm capacitation and sperm membrane integrity were reduced.

Keywords: Infertility, reproductive toxicity, seminal plasma protein, electrophoresis, gossypol, rabbit

\section{INTRODUCTION}

Mammalian seminal plasma contains many distinct components which are important for spermatozoal function and survival (Edwards et al., 1981), although the functions of these various protein components are poorly understood. Antifertility factors from seminal plasma have been described for several species which include decapacitation factors (Zaneveld et al., 1970; Eng and Oliphant 1978), human antifertility factor-1 (Audhya et al., 1987), and rabbit acrosome stabilizing factor (Eng and Oliphant 1978). These factors are believed to inhibit sperm capacitation, acrosome reaction or acrosomal enzymes prior to fertilization.

Issued by The Egyptian Society of Animal Production 
In contrast, several protein factors that promote sperm viability and fertilization have been identified. These include heparin-binding proteins in bull and boar seminal plasma (Miller et al., 1990; Sanz et al., 1993). Recently, Pérez-Pé et al. (2001) noted the ability of seminal plasma proteins to reverse cold-shock membrane damage, thus restoring the surface characteristics of viable-like spermatozoa.

Our recent studies clearly indicated that gossypol has pronounced hazardous effects on seminal characteristics (Taha et al., 2006) and seminal plasma constituents (Shaaban et al., 2008) in male rabbits, which may lead to deleterious productive and reproductive performance. In the present study, rabbits were chosen as an experimental animal owing to the fact that they are excellent model for reproductive toxicological studies. This is because the male rabbit is the smallest, least expensive animal that can be ejaculated with an artificial vagina, where serial semen samples could be obtained for biochemical and fertility evaluations (Foote and Carney 2000).

Moreover daily ingestion of gossypol provokes infertility in various animal species, including humans. The contraceptive effect of gossypol in man was discovered first in China, and still continues to be tested as a favorable candidate as a male contraceptive (Cui et al., 2004).Thus the present study was carried out to evaluate the possible deleterious effect of gossypol on the electrophoretic pattern of rabbit seminal plasma proteins. The discussion will focus on some proteins of interest and offer some insight into their possible biological effect. Comparisons are made between each rabbit seminal plasma protein and other related proteins identified in earlier studies based on similar molecular weights as well as biological functions.

\section{MATERIAL AND METHODS}

\section{Animals and management:}

This study was carried out at the Department of Animal Production, Faculty of Agriculture, Alexandria University, Alexandria, Egypt. Experiments were carried out after the Departmental approval, and were done without any commercial profit purposes for the Authors or the Department. All procedures and experimental protocols were conducted in accordance with the "Guide for the Care and Use of Laboratory Animal" (2002). Fifteen mature male New Zealand white rabbits aged six to eight months and weighing $2.760 \pm 0.39 \mathrm{~kg}$ at the beginning of the experiment were used during the reproductive season (starting in September to avoid summer heat stress, as rabbit semen characteristics vary among seasons where increasing ambient temperature adversely affects semen quality (Hafez and Hafez, 2000)). The rabbits were individually housed in cages. Feed and water were provided ad libitum. The animals were fed pellets consisting of (per $\mathrm{kg}$ ) $330 \mathrm{~g}$ berseem (Trifolium alexandrinum) hay, $170 \mathrm{~g}$ soybean meal, $165 \mathrm{~g}$ ground corn, $160 \mathrm{~g}$ barley, $120 \mathrm{~g}$ wheat bran, $38 \mathrm{~g}$ molasses, $10 \mathrm{~g}$ salt, $4 \mathrm{~g}$ dicalcium phosphate, and $3 \mathrm{~g}$ vitamins. The chemical analysis of the pellets according to the Association of Official Analytical Chemists (AOAC 1995) indicated that it contained (per kg) $175 \mathrm{~g}$ crude protein, $140 \mathrm{~g}$ crude fiber and $27 \mathrm{~g}$ fat. All animals were allowed to adjust to their new environment and tested for semen quality through three weeks before the experiment started.

Experimental design

Gossypol was extracted from cottonseeds and purified according to Boatner (1948) as described by Taha et al. (2006). The rabbits were randomly divided into 3 
groups of 5 animals each, and were assigned at random to one of the following treatments: the first group served as control (the animals were given an equivalent dose of the vehicle consisting of maize oil + acetone); the second and third groups were used to study the effect of the low dose $\left(1 / 100 \mathrm{LD}_{50}, 4 \mathrm{mg} / \mathrm{kg}\right.$ live weight $)$ and high dose $\left(1 / 20 \mathrm{LD}_{50}, 20 \mathrm{mg} / \mathrm{kg}\right.$ live weight) of gossypol. The proper dose for each rabbit was given orally by syringe, directly into the esopharyngeal region, every other day throughout the treatment period, which lasted for 8 wks (i.e. 56 days, which is almost equal to the duration of spermatogenesis in the rabbits, 52 days) (Swierstra and Foote 1965). This period was followed by an 8 wk recovery period when all drugs were withdrawn.

\section{Semen sampling:}

Semen collection was carried out weekly from all animals throughout the 16week experimental period. Ejaculates were obtained using an artificial vagina and a teaser doe. Seminal plasma was separated from ejaculates by centrifugation at 2,000 $\times \mathrm{g}$ for $10 \mathrm{~min}$. The recovered seminal plasma fraction was further centrifuged at $7,500 \times \mathrm{g}$ for $15 \mathrm{~min}$ at $4^{\circ} \mathrm{C}$ and the supernatant was stored at $-20^{\circ} \mathrm{C}$ until analysis. Electrophoretic pattern of seminal plasma proteins

The chemicals used in this study were purchased from Sigma (Sigma Chemical Co., St. Louis, MO, USA). Sodium dodecylsulphate-polyacrylamide gel electrophoresis (SDS-PAGE) was carried out in a discontinuous system (10\%) of polyacrylamide gel according to the method described by Laemmli (1970) using a protean II Vertical Slab Gel Electrophoresis Apparatus (Bio-Rad, Hercules, CA, USA). Seminal plasma samples (pooled samples of each group at the end of each period) containing $50 \mu \mathrm{g}$ of proteins were diluted 1:1 with the sample buffer [25\% glycerol (vol/vol), $2 \%$ SDS (wt/vol), $0.027 \quad M$ Tris- $\mathrm{HCl} \quad \mathrm{pH} \quad 6.8, \quad 5 \% \quad 2-$ mercaptoethanol (vol/vol), $0.018 \%$ EDTA (wt/vol) and $0.1 \%$ bromophenol blue (wt/vol)] and heated at $100^{\circ} \mathrm{C}$ for $5 \mathrm{~min}$. Electrophoresis was carried out for $1 \mathrm{~h}$ at 80 $\mathrm{V}$ at room temperature. A mixture of molecular masses ranging from 6.5 to $205 \mathrm{kDa}$ was used as standards. Gel was stained with $0.025 \%$ Coomassie R (wt/vol). Densitometric analysis of the stained gel was carried out using Gel Doc 2000 with Molecular Analyst software (Bio-Rad).

\section{Statistical analysis:}

Because there was no replication for the treatment, it was not possible to run analysis of variance for the data. Regression analysis of the response of the amount of seminal plasma protein band to the concentration of gossypol was used. The model used was $\mathrm{Y}=\mathrm{a}+\mathrm{bx}$, where $\mathrm{Y}$ : content of peptide band; $\mathrm{a}$ : intercept; $\mathrm{b}$ : regression coefficient and $\mathrm{x}$ : the concentration of gossypol. The variation among the treatments was splitted to sum squares due to regression and sum squares deviation from regression. The latter was used to calculate the variance of the deviation from regression with one d.f. and it was treated as MS of error. Because of the scarcity of d.f. of the error, a significant level of $<0.34$ was used as an indicator that the $b$ value is greater than zero by one standard deviation (SAS 1999).

\section{RESULTS}


In order to elaborate whether the deleterious effect of gossypol on seminal characteristics was related to different protein constituents, seminal plasma from the control and gossypol-treated rabbits were analyzed by sodium dodecyl sulphate polyacrylamide gel electrophoresis (SDS-PAGE). The electrophoretic patterns of seminal plasma proteins of the control and gossypol-treated rabbits throughout the treatment and recovery periods are shown in Figure 1. Densitometric analysis of the stained gel patterns is presented in Table 1. Twenty two bands were identified ranging from a high $200.0 \mathrm{kDa}$ peptide band down to a low $11.0 \mathrm{kDa}$ peptide band. The electrophoretic pattern revealed some common peptides, i.e. three major bands (named F11, F17 and F21) that represent 35\% of the total areas of peptide bands. Their corresponding molecular weights were estimated at 33.0, 21.5 and 13.0 kDa, respectively.

Densitometric analysis of the stained gel patterns allows automatic comparison among the separated bands. Gossypol treatment yielded inconsistent trend, where at the end of the treatment, regression coefficients of the content of seminal plasma peptide bands having $66.0,31.0$ and $23.0 \mathrm{kDa}$ on dose of gossypol were significantly positive. However, as gossypol dose increased, the content of the bands having 70.0 and $11.0 \mathrm{kDa}$ showed significantly negative regression coefficients. Furthermore, the content of seminal plasma peptide bands having 35.0, 44.0 and $93.0 \mathrm{kDa}$ were increased 1.8, 7.7 and 2-3 times, respectively relative to the control, whereas the 18.3, 33.0 and $200.0 \mathrm{kDa}$ peptide bands were lowered to (34-36\%), (54-52\%) and $(32-36 \%)$ [in the low and high doses of gossypol] respectively than control, but linear regression could not be detected because both of the low and the high doses of gossypol exerted similar effects.

After gossypol cessation, the effect of gossypol treatment on the content of 70.0 and $66.0 \mathrm{kDa}$ peptide bands was extended till the end of recovery period. Interestingly, the content of 42.0, 33.0, 27.0, 24.0, 21.5 and 19.8 $\mathrm{kDa}$ peptide bands showed significant regression coefficients at the end of the recovery period although it did not reveal significant response at the end of the treatment period. In addition, the content of $23.0 \mathrm{kDa}$ peptide band showed significantly negative regression coefficient on dose of gossypol at the end of recovery period which was reversed relative to that at the end of treatment period.

\section{DISCUSSION}

Audhya et al. (1987) isolated a high molecular weight (200 kDa) antifertility factor from human seminal plasma that was found to inhibit capacitation (i.e. decapacitation factor) (Van der Ven et al., 1982). This inhibition may ultimately lead to the inability of the spermatozoa to undergo the acrosome reaction (Audhya et al., 1987). Similarly, the F1 (200.0 kDa) protein isolated in the present study from rabbit seminal plasma can be considered as a decapacitation factor. This $200 \mathrm{kDa}$ band was reduced in the gossypol-treated groups by about $30 \%$ of the control value. This reduction was associated with increasing the percentage of altered acrosome in the gossypol-treated rabbits (Taha et al., 2006).

Gatti et al. (1999) reported a protein of $94.0 \mathrm{kDa}$ in ram seminal plasma. This protein matches the sequence of the angiotensin-I converting enzyme (ACE), and exhibited a carboxypeptidase activity which is inhibited by specific blockers of ACE. ACE has been suggested to have a role in the capacitation and acrosome reaction 
processes (Köhn et al., 1998). In the present study, F3 (93.0 kDa) is of almost similar size and therefore may be structurally related to the $94.0 \mathrm{kDa}$ protein found in Gatti's study (1999). The present study revealed an association of the gossypol-induced increase in the content of $93.0 \mathrm{kDa}$ peptide band (Table 1) with increasing the percentage of altered acrosome (Taha et al., 2006), suggesting a similar biological effect of that band and the $94.0 \mathrm{kDa}$ protein band found in Gatti's study (1999).

Table 1. Densitometric quantification of relative areas $(\%)$ of protein bands in seminal plasma at the end of treatment and recovery periods of male rabbits treated with gossypol and their regression coefficients

\begin{tabular}{cccccccccc}
\hline \multicolumn{3}{c}{ Band Mol. Wt. } & \multicolumn{9}{c}{ Treatment } & \multicolumn{4}{c}{ Recovery } \\
no. & kDa & Control & GLD $^{\mathbf{1}}$ & GHD $^{2}$ & b & Control & GLD $^{1}$ & GHD $^{2}$ & b \\
\hline 1 & 200.0 & 1.51 & 1.02 & 0.97 & -0.02 & 1.47 & 1.01 & 1.13 & -0.01 \\
2 & 155.0 & nd $^{3}$ & 0.78 & 1.10 & 0.05 & 1.11 & 0.97 & 1.09 & 0.01 \\
3 & 93.0 & 1.37 & 4.22 & 2.92 & 0.03 & 3.79 & 3.04 & 2.94 & -0.03 \\
4 & 70.0 & 4.13 & 3.24 & nd & $-0.21^{\dagger}$ & 3.19 & 3.30 & nd & $-0.17^{\dagger}$ \\
5 & 66.0 & 1.50 & 3.99 & 7.14 & $0.26^{\dagger}$ & 3.78 & 3.24 & 6.06 & $0.13^{\dagger}$ \\
6 & 57.5 & 4.69 & 5.58 & 5.59 & 0.08 & 5.51 & 6.04 & 6.08 & 0.02 \\
7 & 52.0 & 3.93 & 6.05 & 6.04 & 0.08 & 5.12 & 5.63 & 5.62 & 0.02 \\
8 & 44.0 & 0.32 & 2.47 & 2.52 & 0.08 & 3.10 & 2.57 & 2.59 & -0.02 \\
9 & 42.0 & 4.13 & 5.02 & 4.64 & 0.01 & 4.49 & 4.73 & 5.36 & $0.04^{\dagger}$ \\
10 & 35.0 & 3.25 & 5.93 & 6.11 & 0.11 & 5.40 & 5.99 & 4.90 & -0.04 \\
11 & 33.0 & 10.86 & 5.03 & 5.22 & -0.20 & 5.66 & 5.99 & 7.14 & $0.07^{\dagger}$ \\
12 & 31.0 & 3.17 & 3.14 & 3.25 & $0.01^{\dagger}$ & 5.00 & 5.66 & 5.07 & -0.01 \\
13 & 28.7 & 3.80 & 3.07 & 2.98 & -0.03 & 3.02 & 2.58 & 2.65 & -0.01 \\
14 & 27.0 & 4.53 & 5.07 & 4.30 & -0.02 & 4.73 & 4.50 & 5.25 & $0.03^{\dagger}$ \\
15 & 24.0 & 5.53 & 6.23 & 5.86 & 0.01 & 5.87 & 6.79 & 8.64 & $0.13^{\dagger}$ \\
16 & 23.0 & 4.08 & 3.31 & 5.91 & $0.11^{\dagger}$ & 3.81 & 4.15 & nd & $-0.21^{\dagger}$ \\
17 & 21.5 & 12.02 & 9.17 & 10.52 & -0.03 & 8.66 & 8.55 & 7.25 & $-0.07^{\dagger}$ \\
18 & 19.8 & nd & 3.41 & nd & -0.06 & 3.16 & 2.61 & 4.32 & $0.07^{\dagger}$ \\
19 & 18.3 & 9.48 & 6.23 & 6.04 & -0.13 & 5.33 & 6.16 & 4.67 & -0.05 \\
20 & 14.5 & 4.82 & 4.91 & 4.95 & 0.01 & 5.04 & 3.41 & 6.20 & 0.09 \\
21 & 13.0 & 12.15 & 9.67 & 13.96 & 0.14 & 9.85 & 10.84 & 9.87 & -0.02
\end{tabular}




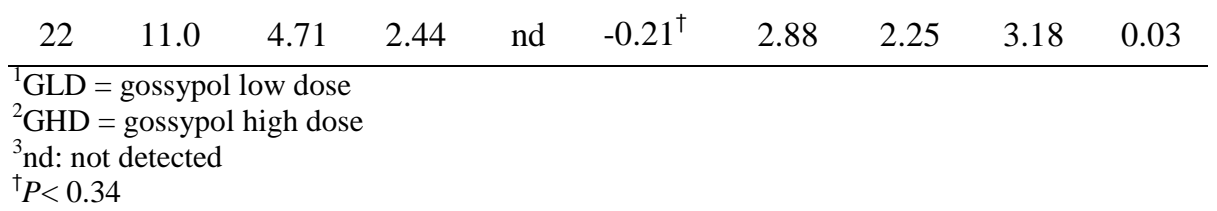

Angiotensin I is converted to angiotensin II by the action of converting enzymes. Angiotensin II accounts for the biologic activity, where it acts directly on the adrenal cortex to stimulate aldosterone secretion and thus plays a central role in the regulation of sodium balance. Accordingly, increasing ACE results in increasing angiotensin II, which stimulates aldosterone secretion and consequently sodium retention. This would explain the increasing level of sodium concentration noted in the seminal plasma of rabbits treated with the high dose of gossypol (Shaaban et al., 2008). Interestingly, sodium level did not change in the low dose-treated group (Shaaban et al., 2008) in spite of the extreme increase of ACE level in this group (Table 1). In the low dose-treated rabbits, this huge amount of ACE could cause an excess production of angiotensin II which is known to suppress plasma renin activity (Ramsay 1983) and, thus, unchanged level of sodium would be expected in this group.

In a study by Davis (1971), it was reported that rabbit seminal plasma contained the peptide protein $70.0 \mathrm{kDa}$. This protein has the ability to bind and fuse with spermatozoa (Davis 1978), and thereby produces changes in the lipid composition of the sperm membranes. This alteration has been suggested to stabilize the plasma membrane of spermatozoa (Shivaji and Bhargava, 1987). The F4 band (70.0 kDa) found in the present study was reduced significantly (by $21 \%$ in the low-dose gossypol-treated group, whereas it disappeared in the high-dose group) suggesting gossypol-induced destabilization of spermatozoa plasma membrane. The decreasing effect of gossypol treatment on the content of the $70.0 \mathrm{kDa}$ peptide band was extended after gossypol cessation, where it decreased in a dose-dependent manner. This is confirmed by the association of decreasing content of $70.0 \mathrm{kDa}$ peptide band (Table 1) with increased percentage of altered acrosome (Taha et al., 2006) as well as lesioned cell membrane of the midpiece (as depicted by electron microscope, Shaaban 2003). This finding would support our view that the $70.0 \mathrm{kDa}$ band noted in the present study exhibits similar biological effects as the band of $70.0 \mathrm{kDa}$ protein found in Davis' study (1971).

Szumowski (1961) reported that the presence of traces of serum albumin in seminal plasma is due to inflammatory tissue exudates. He found a highly significant correlation between the increase of the serum albumin-like electrophoretic fractions of bull seminal plasma and the pathological characteristics of spermatozoa. Therefore, it is possible that some pathological effects of the changes in semen fertility are related to specific alterations in the electrophoretic patterns. This finding is consistent with the present observations in which the serum albumin-like fraction (66.0 kDa band) increased significantly reaching 2.7 and 4.8 - fold compared with the control in the low and high dose-treated groups, respectively (Table 1). This finding coincided with the increased percentages of dead sperm and abnormal sperm as well as altered acrosome observed by Taha et al. (2006) in the gossypol-treated rabbits. Furthermore, the increasing effect of gossypol treatment on the content of $66.0 \mathrm{kDa}$ 
peptide band was extended after gossypol cessation where it increased as gossypol dose increased. This increase observed in the present study is in accordance with the increasing percentages of dead sperm and altered acrosome observed after gossypol cessation in our previous studies (Taha et al., 2006).

Using SDS-PAGE, Kim et al. (1997) reported that rabbit sperm tail fibrous sheath extracts revealed at least 10 protein bands, of which the most intensely stained was the $35.2 \mathrm{kDa}$ band. This band seems to be similar to the F10 peptide band having $35.0 \mathrm{kDa}$ detected in the present study (Table 1). The densitometric quantification of this band indicated an intensity of staining equivalent to 1.8 and 1.9 - folds that of the control in the low and high-dose groups, respectively. This increase in the concentration of sperm tail fibrous sheath protein in seminal plasma of the gossypoltreated rabbits, suggests a further destabilization of sperm structures in response to gossypol treatment. This view is supported by the destructive effects of gossypol upon sperm cell membrane, mitochondrial sheath as well as axoneme as shown by electron micrographs (Shaaban 2003).

In the rest of peptide bands having > $35.0 \mathrm{kDa}$, gossypol treatment resulted in marked increases in the content of peptide bands having 52.0 and $44.0 \mathrm{kDa}$ in which the protein occurred in amounts averaging 1.5 and 7.8 - folds compared to the control. However, due to the scarcity of literature dealing with these protein bands, the increase in their content is difficult to explain.

Several studies have shown that seminal plasma proteins are important agents in sperm capacitation (Thérien et al., 1995; and Galantino-Homer et al., 1997). Bovine seminal plasma (BSP) contains a family of closely-related proteins having $30.0 \mathrm{kDa}$ (collectively called BSP proteins) that exhibit multiple binding and functional properties (Manjunath and Sariam 1987; Desnoyers et al., 1994). They bind to the sperm membrane upon ejaculation, and this binding takes place via choline phospholipids of the sperm membrane (Desnoyers and Manjunath, 1992). Also, these BSP proteins bind to sperm capacitation factors, namely, heparin (Chandonnet et al., 1990) and high-density lipoproteins, HDL (Manjunath et al., 1989), which is secreted into the lumen of the female reproductive tract. The mechanism underlying the heparin-induced capacitation is not known, but the binding of BSP proteins to the sperm membrane appears to increase the number of heparin-binding sites on the sperm surface (Thérien et al., 1995, 1997\&1998). Results suggested that the mechanism by which HDL and BSP proteins stimulate sperm capacitation involves cholesterol efflux (Thérien et al., 1998). The presence of BSP-30 kDa homologus genes in rabbit genomic DNA have been reported by Salois et al. (1999). Additionally, Lee et al. (1985) and Ax et al. (1987) reported that high percentage of abnormal sperm is associated with a reduction in heparin-binding affinity, and that the binding affinity that spermatozoa possess for heparin is positively related to nonreturn rate (Marks and Ax, 1985). Also, the trait most highly correlated with nonreturn rate is the percentage of intact acrosome (Saacke, 1984).

In the present study (Table 1 and Fig. 1), F11 (33.0 kDa) is of similar size and therefore may be structurally related to the BSP-30 kDa indicated above, especially after the investigation of Salois et al. (1999) who reported that genomic DNA of the rabbit possesses a gene with a significant homology to the bovine BSP-30 kDa gene. The densitometric analysis revealed that the $33.0 \mathrm{kDa}$ band was reduced markedly by 54 and $52 \%$ that of control in the low and high-dose groups, respectively. On the 
other hand, the reduction in the content of $33.0 \mathrm{kDa}$ peptide band may result in a reduction in heparin-binding affinity, and this status was associated with increased percentage of abnormal sperm (Taha et al., 2006). This finding is consistent with those reported by Lee et al. (1985) and Ax et al. (1987). After gossypol cessation the content of $33.0 \mathrm{kDa}$ peptide band increased significantly in a dose-dependent manner, and this increase coincided with regaining the percentage of abnormal sperm to its normal level as observed previously during the recovery period (Taha et al., 2006).

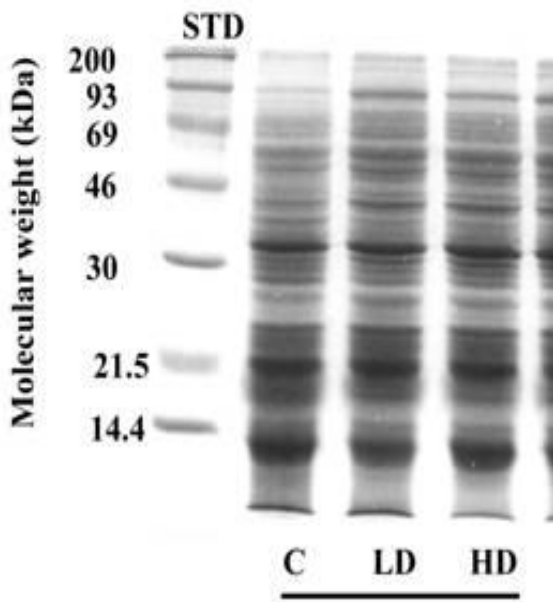

Treatment
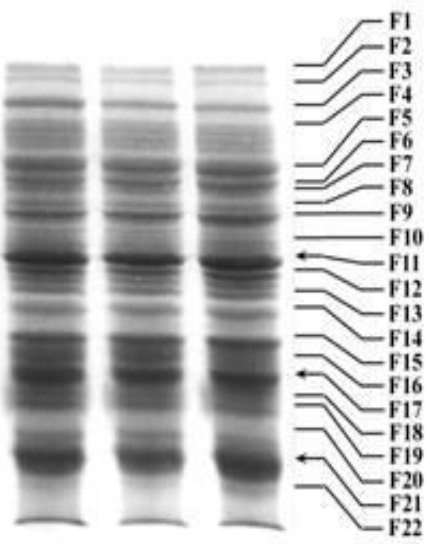

LD HD

Recovery

Fig. 1. SDS-PAGE $(10 \% \mathrm{~T})$ of seminal plasma proteins of male rabbits treated with gossypol. STD: Standard low molecular weight proteins marker (C: Control, LD: Low dose of gossypol, HD: High dose of gossypol)

Several studies have provided direct evidence that specific components of seminal plasma, particularly proteins, are adsorbed onto the surface of ejaculated sperm (Desnoyers and Manjunath 1992; Amann et al., 1999). Some of these adsorbed proteins maintain the stability of the membrane until the process of capacitation that occurs in the female genital tract (Cross, 1996), where their removal is a prerequisite for fertilization (Desnoyers and Manjunath, 1992). The reduced longevity and fertilizing ability of the spermatozoa having the features of premature capacitation has been proposed to be due to their early capacitation state (Watson, 1995). Recently, it has been reported that the lack of seminal plasma proteins to recover sperm membrane integrity of damaged cells could be due to the absence or the decrease of seminal plasma protein of $21.5 \mathrm{kDa}$ (Pérez-Pé et al., 2001). In the present study (Table 1) a decrease in the $21.5 \mathrm{kDa}$ band was found in the low and high dose gossypol-treated groups that amounted to 23 and $12 \%$ below the control value, 
respectively. This decrease was associated with, and may be the reason for, the gossypol-induced increases in the percentages of altered acrosome (Taha et al., 2006) and sperm membrane damage. The reducing effect of gossypol on the content of $21.5 \mathrm{kDa}$ peptide band was extended significantly after gossypol cessation where it decreased significantly in a dose-dependent manner. This reduction coincided with the increased percentage of altered acrosome observed previously during the recovery period of the gossypol-treated rabbit (Taha et al., 2006). This finding may substantiate the functional similarity between this protein and that found in the study of Pérez-Pé et al. (2001).

In a study by Frazer and Bucci (1996), a protein of $18.2 \mathrm{kDa}$ was found in stallion seminal plasma. This protein is similar to one of the equine seminal plasma heparin-binding proteins identified in a separate study (Calvete et al., 1995). Results of the current study (Table 1) indicate that F19 (18.3 kDa) is of similar size and therefore may be structurally related to the $18.2 \mathrm{kDa}$ protein found in Frazer and Bucci's study (1996). The present study revealed a significant decrease in the 18.3 $\mathrm{kDa}$ band in the low and high dose gossypol-treated groups (34 and 36\%, respectively), and was associated with the increase in the percentages of abnormal sperm and altered acrosome found by Taha et al. (2006) in the gossypol-treated rabbits. This finding may provide further support to the possible similarity of this protein to the equine seminal plasma heparin-binding protein.

A thyrotropin releasing hormone - like peptide (TRH-like peptide), also named fertilization - promoting peptide (FPP), was noted in mammalian prostate and semen of humans (Cockle et al., 1989 a) and rabbits (Cockle et al., 1989 b; Thetford et al., 1992). This peptide enhances the fertilization potential of spermatozoa. In rabbit semen, the TRH-like peptide has approximately 50 amino acid residues, which contains a TRH immunoreactive fragment at its C- terminus (Thetford et al., 1992) and has a molecular weight of 10-12 kDa (Cockle et al., $1989 \mathrm{~b}$ ). This polypeptide band appears to be similar to the F22 peptide band of $11.0 \mathrm{kDa}$ found in the present study. The densitometric quantification of this band indicated a significant decrease in the intensity of staining that amounted to $48 \%$ below the control in the low dose gossypol-treated group, whereas it disappeared in the high dose group. The decreasing effect of gossypol on the concentration of this peptide band, suggests a further suppression of the fertilization potential of spermatozoa in the gossypol treated rabbits.

Due to the scarcity of literature dealing with the effect of gossypol on seminal plasma proteins, the role of other proteins which were also affected in the gossypoltreated groups cannot be ruled out.

In conclusion, gossypol treatment induced deleterious effects on rabbit seminal plasma protein concentrations. Gossypol increased the content of some peptide bands associated with increasing acrosome alterations, dead and abnormal sperm and destabilization of sperm structure. Additionally, gossypol caused decreases in other peptide bands related to reduction of sperm capacitation, sperm membrane integrity and fertilization potential of spermatozoa. Furthermore, the detrimental effects of gossypol especially on the 70.0, 66.0 and $21.5 \mathrm{kDa}$ peptide bands were extended after gossypol cessation and seem to be associated with extended increasing acrosome alterations. 


\section{ACKNOWLEDGEMENTS}

The authors wish to thank Dr. Mamdouh El-Rouby, Prof. of Statistics, Faculty of Agriculture, Alexandria University for his advice on the statistical analysis of the data. 


\section{REFERENCES}

Amann, R.P., R.H. Hammerstedt and R.B. Shabanowitz, 1999. Exposure of human, boar, or bull sperm to a synthetic peptide increases binding to an egg-membrane substrate. J. Androl. 20: 34-41.

A.O.A.C., 1995. Association of Official Analytical Chemists. Official Methods of Analysis. $16^{\text {th }}$ ed., VA, Arlington.

Audhya, T., J. Reddy and L.J.D. Zaneveld, 1987. Purification and parital chemical characterization of a glycoprotein with antifertility activity from human seminal plasma. Biol. Reprod. 36: 511-521.

Ax, R. L., G. R. Gilbert and G. E. Shook, 1987. Sperm in poor quality semen from bulls during heat stress have a lower affinity for binding hydrogen-3 heparin. J. Dairy Sci. 70: 195-200.

Boatner, C. H., 1948. Pigments of cottonseed. pp. 215-223. in Cottonseed and Cottonseed Products. Their Chemistry and Chemical Technology. A. E. Bailey, Ed. Wiley, Interscience, New York.

Calvete, J. J., K. Mann, W. Schäfer, L. Sanz, M. Reinert, S. Nessau, M. Raida and E. Töpfer-Petersen, 1995. Amino acid sequence of HSP-1, a major protein of stallion seminal plasma: Effect of glycosylation on its heparin- and gelatin-binding capabilities. Biochem. J. 310: 615-622.

Chandonnet, L., K. D. Roberts, A. Chapdelaine and P. Manjunath, 1990. Identification of heparin-binding proteins in bovine seminal plasma. Mol. Reprod. Dev. 26: 313-318.

Cockle, S. M., A. Aitken, F. Beg, J. M. Morrell and D. G. Smyth, 1989a. The TRHrelated peptide pyroglutamyglutamylprolinamide is present in human semen. FEBS Lett. 252: 113-117.

Cockle, S. M., J. M. Morrell and D. G. Smyth, 1989b. Thyrotropin-releasing hormone-related polypeptides in rabbit prostate and semen are different from those in rabbit hypothalamus. J. Endocrinol. 1: 31-36.

Cross, N. L., 1996. Human seminal plasma prevents sperm from becoming acrosomally responsive to the agonist, progesterone: cholesterol is the major inhibitor. Biol. Reprod. 54: 138-145.

Cui, G. H., Z. L. Xu, Z. J. Yang, Y. Y. Xu and S. P. Xue, 2004. A combined regimen of gossypol plus methyltestosterone and ethinylestradiol as a contraceptive induces germ cell apoptosis and expression of its related genes in rats. Contraception 70: 335-342.

Davis, B. K, 1971. Macromolecular inhibitor of fertilization in rabbit seminal plasma. Proc. Natl. Acad. Sci. USA. 68: 951-955.

Davis, B. K, 1978. Inhibition of fertilizing capacity in mammalian spermatozoa by natural and synthetic vesicles. Am. Oil. Chem. Soc. Monograph 5: 145-158.

Desnoyers, L. and P. Manjunath, 1992. Major proteins of bovine seminal plasma exhibit novel interactions with phospholipids. J. Biol. Chem. 267: 10149-10155.

Desnoyers, L., I. Thérien and P. Manjunath, 1994. Characterization of the major proteins of bovine seminal fluid by two-dimensional polyacrylamide gel electrophoresis. Mol. Reprod. Dev. 37: 425-435.

Edwards, J. J., S. L. Tollaksen and N. G. Anderson, 1981. Proteins of human semen. I. Two-dimensional mapping of human seminal fluid. Clin. Chem. 27: 1335-1340. 
Eng, L. A. and G. Oliphant, 1978. Rabbit sperm reversible decapacitation by membrane stabilization with a highly purified glycoprotein from seminal plasma. Biol. Reprod. 19: 1083-1094.

Foote, R. H. and E. W. Carney, 2000. The rabbit as a model for reproductive and developmental toxicity studies. Reprod. Toxicol. 14: 477-493.

Frazer, G. S. and D. M. Bucci, 1996. Characterization of the major polypeptides of equine seminal plasma by two-dimensional polyacrylamide gel electrophoresis. Theriogenology 46: 1389-1402.

Galantino-Homer, H. L., P. E. Visconti and G. S. Kopf, 1997. Regulation of protein tyrosine phosphorylation during bovine sperm capacitation by a cyclic adenosine 3',5'-monophosphate-dependent pathway. Biol. Reprod. 56:707-719.

Gatti, J-L., X. Druart, Y. Guérin, F. Dacheux and J-L. Dacheux, 1999. A 105- to 94kilodalton protein in the epididymal fluids of domestic mammals is angiotensin Iconverting enzyme (ACE); evidence that sperm are the source of this ACE. Biol. Reprod. 60: 937-945.

Guide for the Care and Use of Laboratory Animals, 2002. Institute of Laboratory animal resources. Commission in life sciences. National research council. National academy press, Washington, DC.

Hafez, E. S. E. and B. Hafez, 2000. Reproduction in Farm Animals. $7^{\text {th }}$ ed. Lipooincott Williams and Wilkins: Philadelphia.

Kim, Y. H., D. M. de Kretser, P. D. Temple-Smith, M. T. Hearn and J. R. McFarlane, 1997. Isolation and characterization of human and rabbit sperm tail fibrous sheath. Mol. Hum. Reprod. 4: 307-313.

Köhn, F-M., C. Muller, D. Drescher, C. Neukamm, K. F. El Mulla, W. Hagele, E. Hinsch, U. F. Habenicht and W-B. Schill, 1998. Effect of angiotensin converting enzyme (ACE) and angiotensins on human sperm functions. Andrologia. 30: 207215.

Laemmli, U. K, 1970. Cleavage of structural proteins during assembly of the head bacteriophage T4. Nature 277: 680-685.

Lee, C. N., R. R. Handrow, R. W. Lenz and R. L. Ax, 1985. Interactions of seminal plasma and glycosaminoglycans on acrosome reactions in bovine spermatozoa in vitro. Gamete. Res. 12: 345-355.

Manjunath, P., Y. L. Marcel, J. Uma, N. G. Seidah, M. Chrétien and A. Chapdelaine, 1989. Apolipoprotein A -I binds to a family of bovine seminal plasma proteins. J. Biol. Chem. 264: 16853-16857.

Manjunath, P. and M. R. Sairam, 1987. Purification and biochemical characterization of three major acidic proteins (BSP-A1, BSP-A2 and BSP-A3) from bovine seminal plasma. Biochem. J. 241: 685-692.

Marks, J. L. and R. L. Ax, 1985. Relationship of nonreturn rates of dairy bulls to binding affinity of heparin to sperm. J. Dairy Sci. 68: 2078-2082.

Miller, D. J., M. A. Winer and R. L. Ax, 1990. Heparin binding proteins from seminal plasma bind to bovine spermatozoa and modulate capacitation by heparin. Biol. Reprod. 42: 899-915.

Pérez-Pé, R., J. A. Cebrian-Pérez and T. Muino-Blanco, 2001. Semen plasma proteins prevent cold-shock membrane damage to ram spermatozoa. Theriogenology 56: 425-434. 
Ramsay, D. J., 1983. Renal hormones. pp. 330-334 in Basic and Clinical Endocrinology. F.S. Greenspan and P.H. Forsham, Eds. Lange Medical Publications: Los Altos, California.

Saacke, R. G., 1984. Semen quality. Importance of and influencing factors. Page 30 in $10^{\text {th }}$ Technical Conference of Artificial Insemination and Reproduction, National Association of Animal Breeders. Columbia: Mo.

Salois, D., M. Ménard, Y. Paquette and P. Manjunath, 1999. Complementary deoxyribonucleic acid cloning and tissue expression of BSP-A3 and BSP-30-kDa: Phosphatidylcholine and heparin-binding proteins of bovine seminal plasma. Biol. Reprod. 61: 288-297.

Sanz, L., J. J. Calvete, K. Mann and H. J. Gabius, 1993. Isolation and biochemical characterization of heparin-binding proteins from boar seminal plasma: A dual role for sperm adhesions in fertilization. Mol. Reprod. Dev. 35: 37-43.

SAS, 1999. SAS user's guide. Statistics, version $8^{\text {th }}$ ed. SAS Institute, Cary, NC.

Shaaban, W. F, 2003. Biological and Biochemical Seminal Changes in Rabbits treated with Gossypol. MSc. Thesis, Fac. of Agric., Alex. Univ.

Shaaban, W. F., T. A. Taha, F. D. EL-Nouty, A. R. EL-Mahdy and M. H. Salem, 2008. Reproductive toxicologic effects of gossypol on male rabbits: biochemical, enzymatic, and electrolytic properties of seminal plasma. Fertil. Steril. 89: 15851593.

Shivaji, S. and P. M. Bhargava, 1987. Antifertility factors of mammalian seminal fluid. BioEssays 7: 13-17.

Swierstra, E. E. and R. H. Foote, 1965. Duration of spermatogenesis and spermatozoon transport in the rabbit based on cytological changes, DNA synthesis and labeling with tritiated thymidine. Am. J. Anat. 116: 401-412.

Szumowski, P., 1961. Les protéins du plasma séminal et les troubles de la fertilité de taureox . pp. 14-19. in Conference at the $4^{\text {th }}$ International Congress of Animal Reproduction, The Hague.

Taha, T. A., W. F. Shaaban, A. R. EL-Mahdy, F. D. EL-Nouty and M. H. Salem, 2006. Reproductive toxicological effects of gossypol on male rabbits: Semen characteristics and hormonal levels. Anim. Sci. 82: 259-269.

Thérien, I., G. Bleau and P. Manjunath, 1995. Phosphatidylcholine-binding proteins of bovine seminal plasma modulate capacitation of spermatozoa by heparin. Biol. Reprod. 52: 1372-1379.

Thérien, I., R. Moreau and P. Manjunath, 1998. Major proteins of bovine seminal plasma and high-density lipoprotein induce cholesterol efflux from epididymal sperm. Biol. Reprod. 59: 768-776.

Thérien, I., S. Soubeyrand and P. Manjunath, 1997. Major proteins of bovine seminal plasma modulate sperm capacitation by high-density lipoprotein. Biol. Reprod. 57: 1080-1088.

Thetford, C. R., J. M. Morrell and S. M. Cockle, 1992. TRH-related peptides in the rabbit prostate complex during development. Biochim. Biophys. Acta. 1115: 252258.

Van der Ven, H. H., H. K. Bhattacharyya, S. Leto and L. J. D. Zaneveld, 1982. Inhibition of human sperm capacitation by a high molecular weight factor from human seminal plasma. Fertil. Steril. 38: 753-755. 
Watson, P. F, 1995. Recent development and concepts in the cryopreservation of spermatozoa and the assessment of their post-thawing function. Reprod. Fertil. Dev. 7: 871-891.

Zaneveld, J. J., P. N. Srivastava and W. L. Williams, 1970. Inhibition by seminal plasma of acrosomal enzymes in intact sperm. Proc. Soc. Exp. Biol. Med. 133: 1172-1174. 
محاولة لتفسير التأثيرات السمية التناسلية للجوسيبول على المستوى الجزيئي في ذكور الأرانب. نمط الهجرة الكهربية لبروتينات البلازما المنوية التئية

طه أحمد طه، ولاء فؤاد شعبان، فرحات الاسوقي النوتي، محمد حلمي سالم قسم الإنتاج الحيو اني، كلية الزراعة (الثاطبي)، جامعة الإسكندرية، جمهورية مصر العربية تحتوي البلازمـا المنويـة في الثدييات على عدة مكونـات معينـة لها أهميـة في وظيفة وحيويـة الحيوانـات

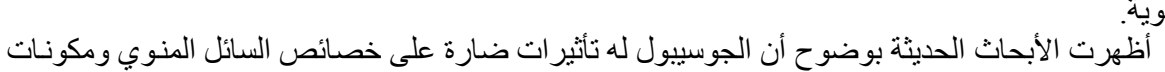

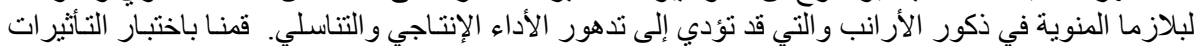

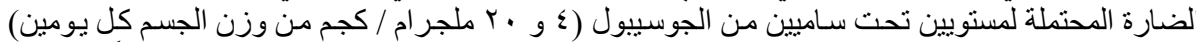

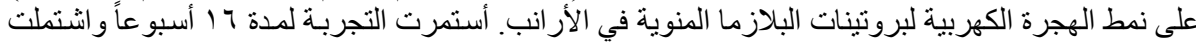

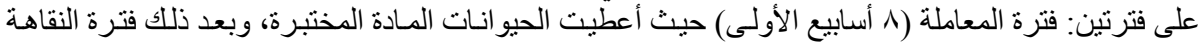

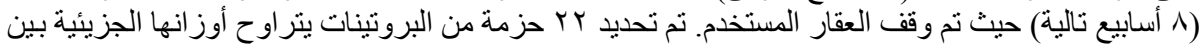

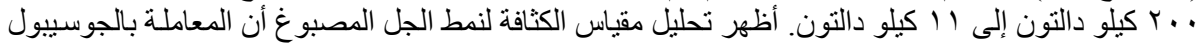

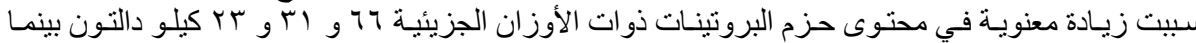

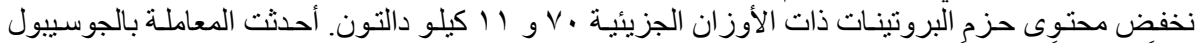

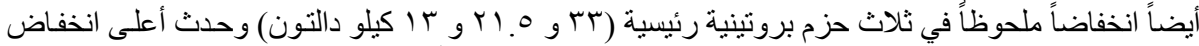

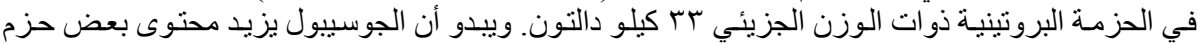

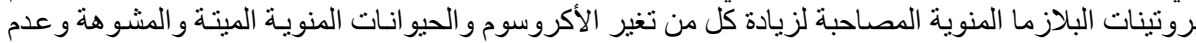

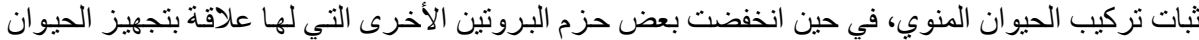

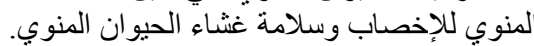

